\title{
Hyvinvointi, kouluonnellisuus ja vahvuuksien käyttö kuudes- ja yhdeksäsluokkalaisilla
}

Niina Fernström, Kaisa Vuorinen ja Lotta Uusitalo

\section{TIIVISTELMÄ}

Tutkimuksessa tarkasteltiin kuudes- ja yhdeksäsluokkalaisten $(n=175)$ kokemuksia hyvinvoinnista, kouluonnellisuudesta ja vahvuuksien käytöstä PERMA-teoriaan (Seligman 2011) perustuen. Tarkoituksena oli selvittää vastaajien subjektiivisia näkemyksiä ja löytää tekijöitä, joiden avulla hyvinvointia voitaisiin tukea koulussa paremmin. Kvantitatiivisen kyselytutkimuksen perusteella kuudes- ja yhdeksäsluokkalaiset voivat keskimäärin hyvin, viihtyvät koulussa, tuntevat vahvuutensa ja osaavat myös käyttää niitä. Aiemmista tutkimuksista poiketen tytöt näyttivät voivan poikia paremmin molemmilla luokka-asteilla, eikä kummankaan sukupuolen (yleinen) hyvinvointi laskenut yläkouluun siirryttäessä. Sen sijaan kouluonnellisuus oli yhdeksäsluokkalaisilla alhaisempaa kuin kuudesluokkalaisilla. Vahvuuksien käytössä ei havaittu eroja eri luokka-asteiden tai sukupuolten välillä. Hyvinvoinnin tarkempi analysointi osoitti kuudes- ja yhdeksäsluokkalaisten poikien kokevan tyttöjä vähemmän sitoutuneisuutta ja yhteenkuuluvuutta ja yhdeksäsluokkalaisten poikien olevan vähemmän sinnikkäitä kuin samanikäiset tytöt. Lisäksi yhdeksäsluokkalaisten poikien vahvuuksien käyttö ei enää korreloinut hyvinvoinnin ja kouluonnellisuuden kanssa kuten muilla tutkittavilla. Tulokset osoittavat, että kouluilla voi olla mahdollisuus lisätä kaikkien oppilaiden hyvinvointia tukemalla osallisuuden kokemuksia ja auttamalla jokaista löytämään vahvuutensa.

Avainsanat: hyvinvointi, kouluonnellisuus, vahvuudet, kuudesluokkalaiset, yhdeksäsluokkalaiset 


\section{ABSTRACT \\ WELL-BEING, SCHOOL-RELATED HAPPINESS AND USAGE OF STRENGTHS AMONG SIXTH AND NINTH GRADERS}

The experiences of PERMA theory-based (Seligman 2011) well-being, school-related happiness and the usage of strengths were examined in 175 sixth and ninth graders. The aim was to study the subjective views of the respondents and find the factors supporting well-being in school. Based on the quantitative survey, the majority of the participants seemed to be doing well, they thrived in school and used their strengths. Unlike in previous studies, well-being was higher among the girls than among the boys in both grades. The boys in sixth and ninth grade experienced less engagement and connectedness than the girls, and the boys in the ninth grade were less persistent than the girls in the same age group. There was no decrease in either genders' general well-being between the sixth to the ninth grade. However, schoolrelated happiness did decrease between the grades. To contrast the other groups, the ninth-grade-boys' strength usage did not correlate with well-being or schoolrelated happiness. The results imply that schools can have potential to increase all students' well-being by supporting participatory experiences and helping them find their strengths.

Key words: well-being, school-related happiness, strengths, adolescence

\section{Johdanto}

asten ja nuorten hyvinvoinnilla on monet kasvot. Onnellisten oppilaiden lisäksi kouluun tulee päivittäin lapsia ja nuoria, joilla on kotona suuria puutteita perusturvassa ja huolenpidossa eikä kenties yhtään ystävää. Lasten hyvinvoinnin ja kasvun tukeminen on monitasoinen haaste, jota voidaan lähestyä niin yksilön ja yhteisöjen kuin myös yhteiskunnan vaikutusmahdollisuuksien kautta (Nivala \& Ryynänen 2019, 224-226). Tämän kolmitasoisen vaikuttamisen kentän läpi tarkasteltuna hyvinvointi koostuu subjektiivisen hyvinvoinnin kokemuksen lisäksi myös yksilöstä riippumattomista tekijöistä, kuten esimerkiksi perhetaustasta sekä yhteisöjen ja yhteiskunnan tarjoamista osallisuuden ja toimijuuden mahdollisuuksista. Suomessakin hyvinvointi jakautuu eriarvoisesti eri yhteiskuntaryhmien välille. Erilaisten lähtökohtien tiedostaminen on ensiarvoisen tärkeää, jotta hyvinvoinnin ja kasvun tukeminen tavoittaa myös ne lapset ja nuoret, jotka tarvitsevat erityistä kasvatuksellista tukea esimerkiksi sosiaalisen huono-osaisuuden vuoksi. (Nivala 2007.) 
Peruskoulun keskeinen tehtävä on edistää tasa-arvoa ja lisätä kaikkien mahdollisuuksia menestyä ja voida hyvin (Perusopetuksen opetussuunnitelman perusteet 2014, 18). Perusopetus (ja varhaiskasvatus) luo sosiaalistavan kontekstin, johon liki jokainen lapsi ja nuori liittyy ja saa kokemuksia ympäröivästä maailmasta koulukulttuurin, koulun henkilökunnan, luokkatovereidensa ja heidän perheidensä välittäminä. Koululla on siten välitön vaikutus lapsen ja nuoren käsitykseen itsestään, paikastaan yhteisössä ja kyvykkyydestään pärjätä maailmassa. Toisaalta kouluilla on myös erityinen mahdollisuus yhteisönä tarjota lapsille ja nuorille kokemus yhteenkuuluvuudesta, osallisuudesta ja toimijuudesta omassa arjessaan. Hyvinvointi koulussa voi loiventaa perhetaustasta tulevia syrjäytymisriskejä, tukea lasta tai nuorta haasteissa ja auttaa vahvuuksien löytämisessä. Hyvinvointia tukevia asioita voidaan sisällyttää opetustyöhön toteuttamalla opetusta niin, että jokainen oppilas saa kokea turvallisuutta ja yhteenkuuluvuutta koulupäivinään. (Thorburn 2014.)

Hyvinvointiin liittyviä taitoja voidaan myös suoraan opettaa. Esimerkiksi resilienssiä, sitoutuneisuutta ja sosiaalisia taitoja on menestyksekkäästi opetettu eri puolilla maailmaa (ks. esim. Seligman, Ernst, Gillham, Reivich \& Linkins 2009; White \& Kern 2018). Samoin vahvuuslähtöisellä opetuksella, jonka tarkoituksena on jokaisen osaamispotentiaalin kirkastaminen ja (usein) luonteenvahvuuksien systemaattinen opettaminen (esim. Vuorinen, Erikivi \& Uusitalo-Malmivaara 2019), on saatu hyviä tuloksia. Vahvuuslähtöisen opetuksen tarkoitus ei ole vain yksilön omien vahvuuksien tuominen esiin vaan myös muissa olevien vahvuuksien havaitseminen ja arvostaminen. Jokaisen osaamispotentiaalin huomioimisella on myönteinen vaikutus hyvinvointiin (Seligman ym. 2009; Vuorinen, Hietajärvi \& Uusitalo 2020). Koulussa ja kouluyhteisössä koettu hyvinvointi ja onnellisuus ovat merkityksellisiä, sillä ne ovat voimakkaasti yhteydessä myös kokonaisvaltaisen onnellisuuden kokemiseen (Vuorinen ym. 2020).

Perusopetus ja sen opetussuunnitelmat heijastavat aina vallalla olevia yhteiskunnallisia, poliittis-ideologisia ja filosofisia näkemyksiä. Kuten Laininen ja Salonen $(2019,61)$ toteavat, koulutusjärjestelmässä on rakenteellinen dilemma, jossa koulutuksen tehtävänä on sekä olemassa olevan yhteiskunnan toisintaminen että sosiaalisen ja kulttuurisen muutoksen aikaansaaminen. Uusimmassa perusopetuksen opetussuunnitelmassa hyvinvoinnin tukeminen on nostettu erityiseksi tavoitteeksi (Perusopetuksen opetussuunnitelman perusteet 2014, 27). Peruskoulun tehtäväksi 
on asetettu oppisisältöopetuksen ohella laajoja ihmisenä kasvun ja yhteiskunnassa pärjäämisen geneerisiä tavoitteita. Tätä osaltaan kuvastavat myös laaja-alaisen osaamisen taidot (mm. itsestä huolehtiminen, yhteistyötaidot, monilukutaito), joita tulisi opettaa läpi peruskoulun (Perusopetuksen opetussuunnitelman perusteet 2014, 18-24). Lisäksi muun muassa erityisopetuksen strategian mukanaan tuoma kolmiportainen tuki (Opetusministeriö 2007, 24) kehottaa ottamaan huomioon yksilöllisesti oppijoiden erilaiset kasvatukselliset ja kehitykselliset tarpeet ja kiinnittämään huomiota jokaisen vahvuuksiin. Erityisopetuksen strategiassa painotetaan inklusiivista opetuksen järjestämistä siten, että lähikoulut vastaisivat kaikkien alueensa oppilaiden koulunkäynnistä. Toteutukset vaihtelevat kuitenkin paljon (Honkasilta, Ahtiainen, Hienonen \& Jahnukainen 2019).

Suomalaisten lasten ja nuorten huonosta kouluviihtyvyydestä on puhuttu paljon. Kuitenkin esimerkiksi Kouluterveyskyselystä selviää, että Suomessa lapset ja nuoret ovat yleisesti ottaen tyytyväisiä elämäänsä ja viihtyvät koulussa. Kouluterveyskysely näyttää toisaalta myös, että tyttöjen elämäntyytyväisyys on alhaisempaa kuin pojilla ja että ylemmille luokille siirryttäessä kaikkien elämäntyytyväisyys laskee ja yksinäisyyden kokemukset lisääntyvät. (Terveyden ja hyvinvoinnin laitos 2019.) Samoin Uusitalo-Malmivaaran (2014) tutkimuksessa näkyy onnellisuuden väheneminen yläkouluun siirryttäessä ja erityisesti tyttöjen kouluonnellisuuden jyrkkä lasku. Eri tutkimuksissa käytetyt toisistaan poikkeavat lähestymiskulmat kertovat samaa kieltä hyvinvoinnin vähenemisestä iän myötä.

Nyt käsillä olevan tutkimuksen tavoitteena on selvittää kuudes- ja yhdeksäsluokkalaisten tyttöjen ja poikien kokemuksia hyvinvoinnista, kouluonnellisuudesta ja vahvuuksien käytöstä ja selvittää niiden välisiä yhteyksiä. Tutkimuksen tarkoituksena on myös tarkastella tulosten valossa koulun mahdollisuuksia tukea lasten ja nuorten hyvinvointia ja tasata eroja hyvinvoinnin kokemuksessa luokka-asteiden ja sukupuolten välillä. Tutkimus perustuu ensimmäisen kirjoittajan pro gradu -työhön (Fernström 2021). Seuraavat kysymykset ohjasivat tutkimusta:

1. Miten hyvin tutkimukseen osallistuneet tytöt ja pojat voivat, kuinka paljon he kokivat kouluonnellisuutta ja käyttivät vahvuuksiaan?

2. Miten hyvinvointi, kouluonnellisuus ja vahvuuksien käyttö eroavat kuudes- ja yhdeksäsluokkalaisten tyttöjen ja poikien välillä? 


\section{Hyvinvoinnin määritteleminen}

Hyvinvointia on määritelty monin tavoin. Vaihtelua esiintyy muun muassa siinä, mistä osa-alueista tai elementeistä hyvinvoinnin katsotaan koostuvan (Dodge, Daly, Huyton \& Sanders 2012). Ruggeri työtovereineen kirjoittaa, että "hyvinvointi on enemmän kuin onnellisuus ja elämäntyytyväisyys" (Ruggeri, Garcia-Garzon, Maguire, Matz \& Huppert 2020, 1). Heidän määritelmänsä mukaan hyvinvointi on yhdistelmä hyvää oloa ja toimintakykyä, onnellisuuden ja tyytyväisyyden kaltaisten positiivisten emootioiden kokemista, oman potentiaalin kehittämistä sekä kontrollin, merkityksellisyyden ja positiivisten ihmissuhteiden olemassaoloa omassa elämässä. Hyvinvointi on siten kattokäsite kokonaisvaltaiselle kokemukselle, jossa on sekä affektiivinen (tunteet, onnellisuuden kokemukset) että kognitiivinen puoli (elämäntyytyväisyys) (ks. myös Diener 2009). Seligmanin (2011) PERMA-teoriassa Ruggerin ym. (2020) hyvinvointimääritelmä toteutuu hyvin, sillä PERMA-teoria sisältää sekä onnellisuuden että elämäntyytyväisyyden kokemisen komponentteja. Kaikkiaan hyvinvointitutkimuksia vertailtaessa on otettava huomioon määritelmien moninaisuus ja se, miten hyvinvoinnin osatekijöitä käytetään vaihtelevasti hyvinvointikäsitteen synonyymeina.

Jayawickreme, Forgeard ja Seligman $(2012,327)$ ovat esittäneet hyvinvoinnin teorioiden jakautuvan kolmeen ryhmään sen perusteella, miten hyvinvointi nähdään niissä saavutettavan. Ensimmäiseen ryhmään kuuluvat teoriat, joiden mukaan hyvinvointia koetaan silloin, kun ihminen saavuttaa haluamansa asiat. Toiseen ryhmään kuuluvat teoriat, joissa ihmisen subjektiivinen kokemus elämäntyytyväisyydestä määrittelee hänen kokonaisvaltaista hyvinvointiaan. Kolmanteen ryhmään kuuluvat puolestaan ne teoriat, jotka lähestyvät hyvinvointia tarpeiden näkökulmasta, ei siis sen kautta, mitä ihminen haluaa tai mistä hän pitää. Dodge ym. (2012) ovat kritisoineet näitä teorioita siitä, etteivät ne onnistu varsinaisesti määrittelemään hyvinvointia, vaan jäävät yrityksiksi kuvata hyvinvointia. Vastauksena tarpeeseen universaalista yksilöitä ja yhteiskuntaa hyödyttävästä hyvinvoinnin määritelmästä Dodge ym. (2012, 229-230) ehdottavat uutta hyvinvoinnin määritelmää, jonka mukaan hyvinvointi muodostuu yksilön resurssien ja hänen kohtaamiensa haasteiden välisestä tasapainosta. Kun yksilön psyykkiset, sosiaaliset ja fyysiset resurssit vastaavat hänen kohtaamiaan psyykkisiä, sosiaalisia ja fyysisiä haasteita, hän voi hyvin.

Hyvinvoiva yhteiskunta koostuu hyvinvoivista yksilöistä. Yksi hyvinvointivaltion tärkeimmistä tehtävistä onkin edistää siellä asuvien yksi- 
löiden hyvinvointia tasaamalla taloudellisesta, sosiaalisesta ja terveydellisestä huono-osaisuudesta syntyvää eriarvoisuutta (Ohisalo, Laihiala \& Saari 2015). Tavoite hyvinvointivaltiosta edellyttääkin sellaista hyvinvoinnin määritelmää, joka ottaa huomioon myös yhteisöjen ja yhteiskunnan merkityksen hyvinvoinnin rakentumisessa. Hyvinvoinnin edistäminen yhteiskunnassa vaatii, että myös yhteiskuntapoliittisissa toimissa tunnistetaan hyvinvoinnin eriarvoistuminen, huono-osaisuuden kasautuminen ja sosioekonomisen taustan merkitys yksilön subjektiivisen hyvinvoinnin kokemuksen ohella (Ohisalo ym. 2015). Sosiaalipedagogisesta tulokulmasta tarkasteltuna yksilöiden ja yhteiskunnan välisen vuorovaikutuksellisen suhteen vankentaminen on hyvinvoinnin kivijalkaa (Madsen 2011). Jokaisen ihmisen sosiaalista kasvua tuetaan hänen omassa yhteisössään ja luodaan toiminnallisia tiloja, joissa kaikki voivat kokea osallisuutta (Raatikainen, Rahikka, Saarnio \& Vepsä 2020).

Hyvinvointipolitiikkaan kuuluu ajatus sekä hyvinvoinnin eriarvoisuuden vähentämisestä että toisaalta myös koko yhteiskunnan hyvinvoinnin edistämisestä (Saikkonen, Karvonen \& Kestilä 2019, 338-339). Hyvinvoinnin tukeminen tulee näin ollen kohdentaa kouluissakin koko ikäluokkaan, ja erityisen tärkeänä voidaan pitää sellaisten väestöryhmien hyvinvoinnin edistämistä, jotka jostain syystä ovat muita heikommassa asemassa. Yksilö tulee kuitenkin aina ymmärtää myös subjektina, joka itse osallistuu oman elämänsä rakentamiseen (Backman 2020).

Tässä tutkimuksessa pohjana on Seligmanin (2011) PERMA-teoria, joka lähtee liikkeelle inhimillisistä tarpeista hyvinvoinnin perustekijöinä. Vaikka Seligman $(2018,3)$ kirjoittaa itsekin, että hyvinvoinnin määritteleminen ei ole yksinkertaista, hän näkee teoriansa mahdollisuutena ymmärtää, mitä tekijöitä tukemalla hyvinvointia voidaan edistää. PERMA-teoria on humanistisesta psykologiasta (ks. esim. Maslow 2013) kumpuava lähestymistapa, jota tässä tutkimuksessa sovelletaan lasten ja nuorten hyvinvointiin koulukontekstissa. PERMA-teorialla on myös yhtymäkohtia itseohjautuvuusteoriaan (Deci \& Ryan 2000) tarvenäkökulman kautta. Sosiaalipedagogisesta näkökulmasta tarkasteltuna PERMA-teoria keskittyy yksilön ja hänen lähimmän yhteisönsä välisiin suhteisiin. Se, missä määrin yksilö voi kokea hyvinvointia omassa lähiympäristössään, riippuu voimakkaasti yhteiskunnallisista tekijöistä. Niihin PERMA-teoria ei erikseen ota kantaa vaan tarkastelee yksilön kokemusta välittömässä sosiaalisessa lähiympäristössään. Nyt käsillä olevassa tutkimuksessa erityisenä kiinnostuksen kohteena on lasten ja nuorten kokema onnellisuus koulus- 
sa, joka on useimmille lapsille ja nuorille perheen jälkeen tärkein sosiaalinen ympäristö.

\section{PERMA-hyvinvointiteoria}

Martin Seligman (2011) kehitti PERMA-teorian vastauksena tarpeeseen laajemmasta hyvinvoinnin ja kukoistuksen teoriasta pelkän "happiologian" asemesta. PERMA-teoria lähestyy hyvinvointia viiden eri osatekijän avulla. Nämä ovat myönteiset tunteet ( $\mathrm{P}=$ positive emotion), sitoutuminen ( $\mathrm{E}=$ engagement $)$, myönteiset ihmissuhteet $(\mathrm{R}=$ relations $)$, merkityksellisyys ( $\mathrm{M}=$ meaning) ja saavuttaminen ( $\mathrm{A}=$ accomplishment $)$.

Nämä osatekijät voivat parhaimmillaan toteutua, kun yksilöllä on riittävästi mahdollisuuksia osallistua yhteisönsä toimintoihin. Sosiaalipedagogisesta näkökulmasta tarkasteltuna on tärkeää pohtia, mikä on se sosiaalistava konteksti, jossa hyvinvoinnin osatekijöiden kokeminen on mahdollista ja kuinka kaikille taataan mahdollisuus kokea niitä.

Myönteisten tunteiden kokeminen helpottaa sosiaalisten suhteiden muodostamista, laajentaa havaintokykyä ja vapauttaa kognitiivista kapasiteettia (Businaro, Pons \& Albanese 2015; Fredrickson 2004; Simel 2020). Barbara Fredricksonin (2001) kehittämän Broaden and build -teorian mukaan myönteisten tunteiden kokeminen lisää tarkkaavuutta ja mahdollisuutta hyötyä ympäristöstä. Kun ihminen kokee myönteisiä tunteita, hänen toimintakykynsä kasvaa, koska hän kokee olevansa turvassa eikä energiaa kulu negatiivisen eliminoimiseen.

Sitoutuneisuus ilmenee Seligmanin (2011) mukaan uppoutumisen kokemuksena. Sitoutuneisuutta kuvastaa Csíkszentmihályin (esim. Csíkszentmihályi \& Csíkszentmihályi 1992) flow-tila, jonka aikana ihminen toimii parhaalla mahdollisella tavalla omia taitojaan ja tietojaan hyödyntäen ja nauttii tekemisestä jopa koko ympäröivän maailman unohtaen (Boniwell 2012; Csíkszentmihályi \& Nakamura 2014).

Myönteiset ihmissuhteet ovat hyvinvoinnin keskeisin tekijä. Muun muassa Boniwell (2012) määrittelee ihmiselämän keskeiseksi tavoitteeksi yhteenkuuluvuuden kokemisen. Norrish $(2015,101)$ on kirjoittanut ihmisten aivojen oleellisena tarkoituksena olevan yhteyden muodostaminen toisiin ihmisiin. Kyky liittyä toisiin on ollut henkiin jäämisemme edellytys (Seligman 2011).

Merkityksellisyys viittaa hyvinvoinnin osatekijänä osallisuuteen, olemassaolon kokemiseen tarkoitukselliseksi ja itsensä kokemiseen osaksi jotain suurempaa (Seligman 2011). Merkityksellisyyden kokeminen liit- 
tyy usein yhteisen hyvän eteen työskentelemiseen (Norrish 2015, 257258). Uusiautin (2014) mukaan merkityksellisyyden kokemiseen liittyy vahvasti myös omien luonteenvahvuuksien hyödyntäminen.

Saavuttaminen liittyy Seligmanin (2011) mukaan valmiiksi saattamiseen, menestykseen ja voittamiseen (ks. myös Leskisenoja 2016). Hyvinvointia lisää itselle merkityksellisten asioiden suorittaminen, vaikka yleisesti ottaen nämä asiat olisivat vähäpätöisiä. Seligman itse mainitsee esimerkkinä tällaisista itselle merkityksellisistä mutta yleisesti ottaen vähäpätöisistä asioista bridgen pelaamisen $(2011,18)$.

\section{Koulun merkitys lasten ja nuorten hyvinvoinnin tukemisessa}

Lasten ja nuorten koulussa kokemaan onnellisuuteen vaikuttavat sekä opiskelumenestys että myönteisten ihmissuhteiden tarjoama turvallinen ja virikkeinen sosiaalinen ympäristö. Tyypillisesti nämä tekijät kietoutuvat yhteen (López-Pérez \& Fernández-Castilla 2018; Tobia, Greco, Steca \& Marzocchi 2019). PERMA-hyvinvointiteoriassa (Seligman 2011) kuten myös itseohjautuvuusteoriassa (Deci \& Ryan 2000) saavuttamiseen ja kyvykkyyteen sekä myönteisiin ihmissuhteisiin ja yhteenkuuluvuuteen liittyvät tekijät muodostavat teorian rungon. Ne ovat myös lapsuuteen ja nuoruuteen kuuluvia olennaisia hyvinvoinnin tekijöitä, joissa koulukontekstilla on suuri merkitys.

Kouluonnellisuus heijastuu myös yksilön kokonaisvaltaiseen onnellisuuden kokemukseen (Badri, Al Nuaimi, Guang, Al Sheryani \& Al Rashedi 2018; Vuorinen ym. 2020). Aiemmat suomalaiset tutkimukset ovat osoittaneet koulussa koetun onnellisuuden ja yleisen onnellisuuden korreloivan vahvasti (Uusitalo-Malmivaara 2012; 2014). Oppimisvaikeuksilla ei ole osoitettu olevan suoraa yhteyttä koulussa koettuun tyytyväisyyteen (McCullough \& Huebner 2003), vaikka toisaalta suomalaistutkimuksen mukaan erityisluokkaa käyvien kouluonnellisuus oli muita matalammalla tasolla (Uusitalo-Malmivaara ym. 2012). Tulokseen vaikuttivat todennäköisesti lukuisat seikat, sillä oppilaat voivat päätyä erityisluokalle monista eri syistä. Thuneberg (2007) kirjoittaa, ettei riitä, että enemmistö oppilaista voi hyvin, vaan psyykkisiä perustarpeita tukemalla (viitaten itseohjautuvuusteoriaan, Deci \& Ryan 2000) voidaan parantaa kaikkien hyvinvointia. Mitä enemmän oppilas tuntee voivansa ohjata oppimistaan ja kuuluvansa yhteisöön, sitä paremmin hän voi hyväksyä myös ulkopuolisia tavoitteita (Thuneberg 2007, 6, 10). 
Harinen ja Halme $(2012$, 65) hahmottavat kouluhyvinvoinnin tukemisen monitasoiseksi tehtäväksi, johon vaikuttavat muun muassa rakenteelliset ja fyysiset olosuhteet, koulussa koettujen vuorovaikutussuhteiden laatu ja toisaalta myös esimerkiksi erilaiset kouluille kohdennetut resurssit. Harinen ja Halme (2012) suosittelevatkin, että kouluhyvinvoinnin edistämiseksi kouluissa toimittaisiin yhä enemmän YK:n lapsen oikeuksien sopimuksen (Unicef 1989) viitekehyksessä. Sopimus nostaa keskiöön aktiivisen pyrkimyksen lasten ja nuorten yhdenvertaisuuteen sekä lasten edun ensisijaisuuteen kaikissa päätöksentekoprosesseissa.

\section{Omien vahvuuksien tunteminen}

Vahvuudet ovat taitoja ja taipumuksia, joiden käyttäminen tuntuu yksilölle luontaiselta, tarkoituksenmukaiselta ja energisoivalta (Govindji \& Linley 2007, 114). Vahvuuksiin keskittyvällä kasvatuksella on juurensa ratkaisukeskeisyydessä ja positiiviseksi psykologiaksi kutsutussa paradigmassa, joka tutkii yksilöissä ja yhteisöissä olevia toimivia tekijöitä ja rakenteita (Baumgardner \& Crothers 2014; Boniwell 2012; Huppert \& So 2011). Omien vahvuuksien tunnistaminen on oman osaamisensa tunnistamista. Vahvuuksiin keskittyvä kasvatus tähtää hyvän tunnustamiseen ja tunnistamiseen itsessä, toisissa ja ympäröivässä maailmassa. Vaistelan $(2019,108)$ mukaan kouluissa tulisi yksilökeskeisyyden sijaan kasvattaa lapsia "maailmakeskeisiksi", jolloin minuutta tarkasteltaisiin myös sen kautta, miten olemme parhaalla tavalla yksilöinä yhteisöissämme, yhteiskunnassamme ja maailmassamme. Vahvuuksiin keskittyvässä kasvatuksessa yhdistyvät jokaisen yksilön erityisyyden ja osaamispotentiaalin tunnustaminen ja Vaistelan (2019) kuvaama maailmakeskeinen yhteisöllisyyden tukeminen.

Omien vahvuuksien tunnistaminen ja käyttö erilaisissa tilanteissa ennustavat elämäntyytyväisyyttä ja menestymistä monilla elämänaloilla (Gillham ym. 2011; Govindji \& Linley 2007; Park, Peterson \& Seligman 2004; Proctor, Maltby \& Linley 2011; Wagner, Gander, Poyer \& Ruch 2020). Vahvuuksien kautta toimiminen on yhteydessä koulussa koettuun onnellisuuteen, koulutyöhön sitoutumiseen ja opinnoissa menestymiseen (Vuorinen ym. 2020; Weber, Wagner \& Ruch 2016). Vahvuuksien käyttö on myös yhteydessä PERMA-teorian eri osa-alueisiin (Seligman 2011; Wagner ym. 2020).

Aiemmat tutkimukset ovat osoittaneet lasten ja nuorten hyvinvoinnin olevan Suomessa korkealla tasolla, mutta vähenevän yläluokille siirryttäessä (Terveyden ja hyvinvoinnin laitos 2019; Uusitalo-Malmivaara 
2014). Erityisesti tyttöjen hyvinvoinnin on todettu laskevan ja koulu-uupumuksen kasvavan murrosiän kynnyksellä. Syitä tähän on etsitty kasaantuvista, moniulotteisista paineista ja tyttöjen suuremmasta tunnollisuudesta vastata odotuksiin (Salmela-Aro, Kiuru, Pietikäinen \& Jokela 2008; Uusitalo-Malmivaara 2014). Murrosikäisillä tytöillä on myös enemmän terveysongelmia kuin pojilla (Rask, Åstedt-Kurki, Paavilainen \& Laippala 2003). Kaikkiaan ikävuodet 12-15 merkitsevät astumista lapsuudesta nuoruuteen ja sisältävät fysiologisten ja psykologisten muutosten ohella vastuiden kasvamista ja oman tien etsimistä. Suurin osa nuorista suoriutuu tästä ikävaiheesta ilman vakavia kriisejä (Rask ym. 2003).

Omien vahvuuksien hyödyntäminen voi vähentää sekä tyttöjen että poikien uupumusta, parantaa onnistumisen mahdollisuuksia ja lisätä sekä koulussa että yleisesti koettua hyvinvointia siirryttäessä alakoulusta yläkouluun (Wagner ym. 2020). Tässä tutkimuksessa tarkastelemme, miten yleinen hyvinvointi, kouluonnellisuus ja vahvuuksien käyttö on yhteydessä toisiinsa kuudes- ja yhdeksäsluokkalaisilla tytöillä ja pojilla.

\section{Tutkimuskohde, aineiston hankinta ja analyysi}

Tutkimusaineisto kerättiin syksyllä 2017 sähköisellä lomakkeella pääkaupunkiseudun kolmen koulun (alakoulu, yläkoulu ja yhtenäiskoulu) kuudesluokkalaisilta ( $n=108$, tyttöjä 58 ja poikia 50, keski-ikä 11,8 vuotta) ja yhdeksäsluokkalaisilta ( $n=67$, tyttöjä 37 ja poikia 30 , keski-ikä 14,7 vuotta) oppilailta kouluaikana opettajien johdolla. Käsittelimme tutkimuksessa vain kahta sukupuolta ja on mahdollista, että ne oppilaat, jotka eivät identifioi itseään tytöksi tai pojaksi, ovat jättäneet vastaamatta. Kuudennet ja yhdeksännet luokat valittiin, koska molemmat luokka-asteet ovat siirtymävaiheen kynnyksellä ja siksi hyvinvointikokemusten tutkiminen on erityisen kiinnostavaa: Mitä alakouluaikana on tapahtunut ja mikä on tilanne sen päättyessä? Entä mikä on vastaava tilanne yläkoulussa? Luokat olivat yleisopetusryhmiä, joissa saattoi olla mukana erityistä ja tehostettua tukea tarvitsevia oppilaita. Luokat osallistuivat vapaaehtoisina Positiivisen CV:n (PCV) kehittämistyöhön osana SITRAn Ratkaisu100-kilpailua (Sitra 2017, ks. myös Positive Learning 2021). Aineistokeruu oli osa alkumittausta, joka tehtiin ennen PCV-interventiota (tulokset raportoitu muualla). Tutkittavilla ei tiettävästi ollut kokemusta vahvuuskasvatuksesta ennen tutkimukseen osallistumista. Kunta, koulut ja oppilaiden huoltajat antoivat luvat tutkimuksen toteuttamiseen, ja tutkimukseen osallistuminen oli lapsille ja nuorille vapaaehtoista. 
Hyvinvoinnin, kouluonnellisuuden ja vahvuuksien käytön selvittämiseen käytettiin kolmea kvantitatiivista, aiemmin suomalaisessa tutkimuksessa testattua mittaria (EPOCH, KOM ja SUS). Lisäksi kyselylomakkeessa oli kysymyksiä sosiaalisesta kompetenssista ja kvalitatiivisia selontekopyyntöjä positiivisesta palautteenannosta (tulokset raportoidaan muualla). Taustamuuttujina kysyttiin ikä, luokka ja sukupuoli.

EPOCH, lasten ja nuorten hyvinvointimittari (Kern, Benson, Steinberg \& Steinberg 2016) koostuu 20 väittämästä, jotka mittaavat sitoutuneisuutta (Engagement), sinnikkyyttä (Perseverance), optimismia (Optimism), yhteenkuuluvuutta (Connectedness) ja onnellisuutta (Happiness). Kustakin edellä mainitusta viidestä osa-alueesta on neljä positiivista väittämää, joihin vastataan asteikolla 1 (en melkein koskaan) - 5 (lähes aina). Esimerkkiväittämät näistä osa-alueista ovat "Uppoudun täysin siihen mitä teen" (sitoutuneisuus), "Teen loppuun mitä ikinä aloitankaan" (sinnikkyys), "Uskon, että minulle tulee tapahtumaan hyviä asioita" (optimismi), "Elämässäni on ihmisiä, jotka todella välittävät minusta" (yhteenkuuluvuus) ja "Tunnen oloni onnelliseksi" (onnellisuus). EPOCH-mittari on kehitetty lapsilla ja nuorilla käytettäväksi, ja se pohjautuu Seligmanin (2011) PERMA-hyvinvointiteoriaan. EPOCH-hyvinvointimittarin sisäinen johdonmukaisuus oli tässä aineistossa erittäin hyvä, $\alpha=0,92$.

KOM-kouluonnellisuusmittari (Ivens 2007) selvittää oppilaiden koulussa koettua ja kouluun liittyvää onnellisuutta. Mittari kehitettiin alun perin koulukiusaamiskokemusten vaikutusten selvittämiseksi, ja se on nimetty "koululaisten onnellisuusmittariksi" ("Happiness measure for school children"). Monipuolisten väittämiensä perusteella mittarin voisi hyvinkin sanoa selvittävän yleisempää kouluun liittyvää hyvinvointia kuin onnellisuutta, mutta käännöksessä on pysytty uskollisena alkuperäiselle nimelle (Uusitalo-Malmivaara 2012). Mittarissa on sekä positiivisia (esim. "Koulu tuntui minusta turvalliselta paikalta") että negatiivisia väittämiä (esim. "Halusin antaa periksi"), ja niihin vastataan asteikolla 1 (erittäin paljon eri mieltä) - 4 (erittäin paljon samaa mieltä). Tässä tutkimuksessa käytettiin KOM-versiota, jossa oli alkuperäisen 30 väittämän sijaan 25 väittämää kuten useissa suomalaistutkimuksissa aiemmin (Uusitalo-Malmivaara 2012; Vuorinen ym. 2020). Kouluonnellisuuden sisäinen johdonmukaisuus oli aineistossamme hyvä, $\alpha=0,90$.

SUS, vahvuuksien käytön mittari (Strength Usage Scale, Govindji \& Linley 2007), on lasten ja nuorten vahvuuksien tuntemista ja käyttöä mittaava alun perin 14 väittämästä koostuva työkalu, johon vastataan astei- 
kolla 1 (ei sovi minun lainkaan) - 5 (sopii minuun erittäin hyvin). Tässä tutkimuksessa mittarista käytettiin seitsemästä positiivisesta väittämästä (esim."Voin tehdä säännöllisesti sitä, mitä osaan parhaiten”) koostuvaa versiota, joka on osoittautunut toimivaksi aiemmissa suomalaisissa tutkimuksissa (Vuorinen ym. 2020). Vahvuusmittarin sisäinen johdonmukaisuus oli aineistossamme erittäin hyvä, $\alpha=0,92$.

Ensimmäiseen tutkimuskysymykseen (miten hyvin tytöt ja pojat voivat, kuinka paljon he kokivat kouluonnellisuutta ja käyttivät vahvuuksiaan) saatiin vastaus hyvinvoinnin $(\mathrm{EPOCH})$, kouluonnellisuuden $(\mathrm{KOM})$ ja vahvuuksien käytön (SUS) mittareiden kuvailevilla tunnusluvuilla. Lisäksi hyödynsimme Pearsonin korrelaatioita selvittääksemme, kuinka hyvinvointi, kouluonnellisuus ja vahvuuksien käyttö ovat yhteydessä toisiinsa. Koska hyvinvoinnin kokemuksessa oli tilastollisesti merkitsevä ero tyttöjen ja poikien välillä, jaoimme jatkoanalyysissä hyvinvoinnin EPOCH-mittarin vielä viiteen sen mittaamaan osatekijään saadaksemme tarkempaa tietoa hyvinvoinnin kokemuksen eroista vertailtavien ryhmien välillä.

Toiseen tutkimuskysymykseen (miten hyvinvointi, kouluonnellisuus ja vahvuuksien käyttö eroavat kuudes- ja yhdeksäsluokkalaisten tyttöjen ja poikien välillä) vastattiin vertailemalla hyvinvoinnin, kouluonnellisuuden ja vahvuuksien käytön kokemuksia riippumattomien otosten $\mathrm{t}$-testeillä. Efektikokojen laskemiseen käytettiin Cohenin $d: t a ̈$.

Kaikki kvantitatiiviset analyysit tehtiin SPSS 27.0 -ohjelmalla. Puuttuvia arvoja ei aineistossa ollut, koska kyselylomaketta ei voinut palauttaa vastaamatta kaikkiin väittämiin. Kuitenkin muutama vastaus oli jäänyt tuntemattomasta syystä tallentumatta. Nämä olivat sattumanvaraisia, eikä näitä osittain tai kokonaan puuttuvia yksittäisiin mittareihin osuneita puuttuvia tapauksia otettu mukaan analyyseihin tai korvattu. Poikkeavia havaintoja aineistossa antoi kolme kuudesluokkalaista. Poika, jonka keskiarvot jokaisesta mittarista olivat neljä hajonnanmittaa keskiarvoa alhaisemmat, poistettiin aineistosta. Vahvuuksien käytöstä tasan yksi keskiarvoksi saaneen tytön vastaukset poistettiin kyseisestä mittarista. Samoin poistettiin hyvinvointimittarin yhteenkuuluvuuden osa-alueelta tytön antama poikkeava tulos, joka oli yli kolme hajonnanmittaa keskiarvoa alhaisempi.

Mikään jakaumista ei noudattanut normaalijakaumaa, mistä johtuen tulokset tarkistettiin vielä epäparametrisella Mann Whitneyn testillä. Eri analyysit eivät tuottaneet keskenään tilastollisesti merkitseviä eroja, ja vain parametriset tulokset raportoitiin. 


\section{Tyttöjen ja poikien kokemukset hyvinvoinnista, kouluonnellisuudesta ja vahvuuksien käytöstä}

Kaikkiaan vastaajien hyvinvointi oli korkealla tasolla (Taulukko 1, ks. myös Fernström 2021). EPOCH-hyvinvointimittarin keskiarvo asteikolla 1-5 oli 3,92 eli vastaajat kertoivat tuntevansa sitoutuneisuutta, olevansa sinnikkäitä ja optimistisia ja kokevansa yhteenkuuluvuutta ja onnellisuutta keskimäärin usein. Hajonta ei ollut suurta eikä erilaista sukupuolten välillä. Keskiarvovertailu osoitti tyttöjen voivan tilastollisesti erittäin merkitsevästi poikia paremmin, ja efektikoko 0,52 osoitti ryhmien välisen eron olevan keskikokoinen.

Kouluonnellisuusmittarin keskiarvo asteikolla 1-4 oli 3,19 kertoen, että kouluun tultiin pääsääntöisesti mielellään ja siellä koettiin enimmäkseen myönteisiä tunteita. Sukupuolten välillä ei havaittu eroa. Vastaukset eivät tälläkään mittarilla mitattuina hajonneet paljon, eikä hajonnoissa ollut eroa sukupuolten välillä. Vahvuuksien käytön mittarin keskiarvo 3,77 asteikolla 1-5 kertoi oppilaiden pääosin tunnistavan omia vahvuuksiaan ja pystyvän käyttämään niitä. Sukupuolten välillä ei ollut eroa vahvuuksien käytössä. Keskihajonnat eivät olleet suuret eivätkä poikenneet sukupuolten välillä. Koko vastaajajoukossa hyvinvointi, kouluonnellisuus ja vahvuuksien käyttö korreloivat keskenään tilastollisesti erittäin merkitsevästi (Taulukko 1). Vahvuuksien käyttö korreloi hieman vähemmän hyvinvoinnin ja kouluonnellisuuden kanssa kuin hyvinvointi ja kouluonnellisuus keskenään.

\section{Kouluonnellisuus laskee yhdeksännellä luokalla}

Kuudes- ja yhdeksäsluokkalaisten välillä ei ollut eroja hyvinvoinnin kokemuksessa eikä eri luokkia käyvien tyttöjen tai poikien välillä. Sen sijaan luokkien sisäinen vertailu osoitti sekä kuudennella että yhdeksännellä luokalla tyttöjen voivan poikia paremmin (Taulukko 1). Erot olivat pienet mutta merkitsevät ja efektikoot $(0,48$ ja 0,63 , vastaavasti) kertoivat erojen olevan keskikokoiset. Kouluonnellisuudessa kuudes- ja yhdeksäsluokkalaisten välillä havaittiin tilastollisesti merkitsevä ero kuudesluokkalaisten hyväksi. Efektikoko oli pienehkö, 0,41. Sukupuolten välillä ei ollut tilastollisesti merkitsevää eroa kummallakaan luokka-asteella. Vahvuuksien käytössä ei ollut tilastollisesti merkitsevää eroa luokka-asteiden eikä sukupuolten välillä.

Hyvinvoinnin, kouluonnellisuuden ja vahvuuksien käytön keskinäiset korrelaatiot vaihtelivat hieman sukupuolten ja luokka-asteiden välillä. 
Hyvinvoinnin ja kouluonnellisuuden välinen korrelaatio oli kuudesluokkalaisilla tytöillä .55, $p<.001$, pojilla $.72, p<.001$, yhdeksäsluokkalaisilla tytöillä .65, $p<.001$ ja pojilla $.50, p<.01$. Hyvinvoinnin ja vahvuuksien käytön välinen yhteys oli kuudesluokkalaisilla tytöillä .70, $p<.001$, pojilla 57 , $p<.001$ ja yhdeksäsluokkalaisilla tytöillä $.46, p<.01$. Kouluonnellisuuden ja vahvuuksien käytön välinen yhteys oli kuudesluokkalaisilla tytöillä .53, $p<.001$, pojilla $.42, p<.01$ ja yhdeksäsluokkalaisilla tytöillä $.51, p<.01$.Yhdeksäsluokkalaisilla pojilla ei ollut yhteyttä hyvinvoinnin ja vahvuuksien käytön eikä kouluonnellisuuden ja vahvuuksien käytön välillä.

Hyvinvoinnin kokemusten tarkemmaksi tarkastelemiseksi EPOCH-hyvinvointimittari jaettiin viiteen osa-alueeseen (kussakin neljä väittämää). Väittämät tuottivat reliabiliteetiltaan hyvät osa-aluemittarit, sitoutuneisuuden $\alpha=0,84$, sinnikkyyden $\alpha=0,76$, optimismin $\alpha=0,80$, yhteenkuuluvuuden $\alpha=0,81$ ja onnellisuuden $\alpha=0,89$. Vastauksia vertailtiin osa-alueit-

Taulukko 1 Hyvinvoinnin, kouluonnellisuuden ja vahvuuksien käytön kuvailevat tunnusluvut, $t$-testiarvot ja korrelaatiot

\begin{tabular}{|c|c|c|c|c|c|c|c|c|c|c|c|c|}
\hline & \multicolumn{4}{|c|}{ Tytöt } & \multicolumn{4}{|c|}{ Pojat } & \multicolumn{4}{|l|}{ Ero } \\
\hline & $n$ & $K A$ & $K H$ & $95 \% \mathrm{Cl}$ & $n$ & $K A$ & $K H$ & $95 \% \mathrm{Cl}$ & $t$ & $d f$ & $p$ & $d$ \\
\hline Hyvinvointi & 94 & 4,05 & 0,56 & {$[3,94,4,17]$} & 79 & 3,76 & 0,56 & {$[3,63,3,88]$} & 3,46 & 171 & $<.001$ & 0,52 \\
\hline Kouluonnellisuus & 94 & 3,21 & 0,45 & {$[3,12,3,31]$} & 78 & 3,16 & 0,43 & {$[3,07,3,26]$} & 0,76 & 170 & n.s & - \\
\hline \multirow[t]{2}{*}{ Vahvuuksien käyttö } & 93 & 3,81 & 0,67 & {$[3,67,3,95]$} & 78 & 3,72 & 0,80 & {$[3,54,3,90]$} & 0,84 & 169 & n.s & - \\
\hline & \multicolumn{4}{|c|}{ 6. -luokkalaiset } & \multicolumn{4}{|c|}{ 9. -luokkalaiset } & \multicolumn{4}{|l|}{ Ero } \\
\hline Hyvinvointi & 106 & 3,97 & 0,59 & {$[3,85,4,08]$} & 67 & 3,84 & 0,55 & {$[3,71,3,97]$} & 1,43 & 171 & n.s & - \\
\hline Kouluonnellisuus & 106 & 3,26 & 0,44 & {$[3,17,3,34]$} & 66 & 3,08 & 0,43 & {$[2,98,3,19]$} & 2,56 & 170 & $<.05$ & 0,41 \\
\hline \multirow[t]{2}{*}{ Vahvuuksien käyttö } & 104 & 3,80 & 0,72 & {$[3,66,3,94]$} & 67 & 3,71 & 0,75 & {$[3,53,3,90]$} & 0,77 & 169 & n.s & - \\
\hline & \multicolumn{4}{|c|}{ 6. -luokkalaiset tytöt } & \multicolumn{4}{|c|}{ 6. -luokkalaiset pojat } & \multicolumn{4}{|l|}{ Ero } \\
\hline Hyvinvointi & 57 & 4,10 & 0,56 & {$[3,95,4,24]$} & 49 & 3,82 & 0,60 & {$[3,64,3,99]$} & 2,49 & 104 & $<.05$ & 0,48 \\
\hline Kouluonnellisuus & 58 & 3,28 & 0,43 & {$[3,17,3,39]$} & 48 & 3,23 & 0,44 & {$[3,10,3,36]$} & 0,60 & 104 & n.s & - \\
\hline \multirow[t]{2}{*}{ Vahvuuksien käyttö } & 56 & 3,81 & 0,71 & {$[3,62,4,00]$} & 48 & 3,79 & 0,75 & {$[3,58,4,01]$} & 0,10 & 102 & n.s & - \\
\hline & \multicolumn{4}{|c|}{ 9. -luokkalaiset tytöt } & \multicolumn{4}{|c|}{ 9. -luokkalaiset pojat } & \multicolumn{4}{|l|}{ Ero } \\
\hline Hyvinvointi & 37 & 3,99 & 0,57 & {$[3,80,4,17]$} & 30 & 3,66 & 0,48 & {$[3,48,3,84]$} & 2,51 & 65 & $<.05$ & 0,63 \\
\hline Kouluonnellisuus & 36 & 3,11 & 0,47 & {$[2,95,3,26]$} & 30 & 3,05 & 0,38 & {$[2,91,3,20]$} & 0,48 & 64 & n.s & - \\
\hline \multirow[t]{2}{*}{ Vahvuuksien käyttö } & 37 & 3,81 & 0,62 & {$[3,61,4,02]$} & 30 & 3,59 & 0,88 & {$[3,26,3,92]$} & 1,22 & 65 & n.s & - \\
\hline & \multicolumn{4}{|c|}{ Koko aineisto } & \multicolumn{3}{|c|}{ Hyvinvointi } & \multicolumn{2}{|c|}{ Kouluonnellisuus } & \multicolumn{3}{|c|}{ Vahvuuksien käyttö } \\
\hline Hyvinvointi & 173 & 3,92 & 0,58 & {$[3,83,4,00]$} & \multicolumn{3}{|c|}{-} & & & & & \\
\hline Kouluonnellisuus & 172 & 3,19 & 0,44 & {$[3,12,3,26]$} & \multicolumn{3}{|c|}{$.62^{* * *}$} & \multicolumn{2}{|l|}{-} & & & \\
\hline Vahvuuksien käyttö & 171 & 3,77 & 0,73 & {$[3,66,3,88]$} & \multicolumn{3}{|c|}{$.53^{* * *}$} & \multicolumn{2}{|l|}{$.42^{* * *}$} & \multicolumn{3}{|c|}{-} \\
\hline
\end{tabular}

Huom. 1. EPOCH Nuorten hyvinvointi, asteikko 1-5, KOM Kouluonnellisuus, asteikko 1-4, SUS Vahvuuksien käyttö 1-5 Huom. 2. Pearson korrelaatiot ${ }^{* *}=p<.001$ 
tain sukupuolten välillä molemmilla luokka-asteilla. Jokainen mitatusta viidestä osa-alueesta sai keskiarvokseen yli kolme, eli sekä tytöt että pojat kokivat jokaista hyvinvoinnin osa-aluetta vähintään usein.

Kuudesluokkalaisten tyttöjen ja poikien välillä oli tilastollisesti merkitsevä ero tyttöjen hyväksi sitoutuneisuuden, $\mathrm{t}(106)=2,93, \mathrm{p}<.01$, ja yhteenkuuluvuuden, $\mathrm{t}(104)=2,36, \mathrm{p}<.05$, osa-alueilla (Kuvio 1). Efektikoot olivat Cohenin d:llä mitattuina (0,56, sitoutuneisuus ja 0,46 yhteenkuuluvuus) keskisuuret. Yhdeksäsluokkalaisten tyttöjen ja poikien välillä oli tilastollisesti merkitsevä ero tyttöjen hyväksi sitoutuneisuuden, $t(65)=2,35, p<.05$, sinnikkyyden, $t(65)=2,78, p<.01$, ja yhteenkuuluvuuden, $t(65)=3,40$, $p<.01$, osa-alueilla (Kuvio 1). Näiden efektikoot olivat 0,57 (sitoutuneisuus), 0,70 (sinnikkyys) ja 0,81 (yhteenkuuluvuus) eli keskikokoisesta suureen.

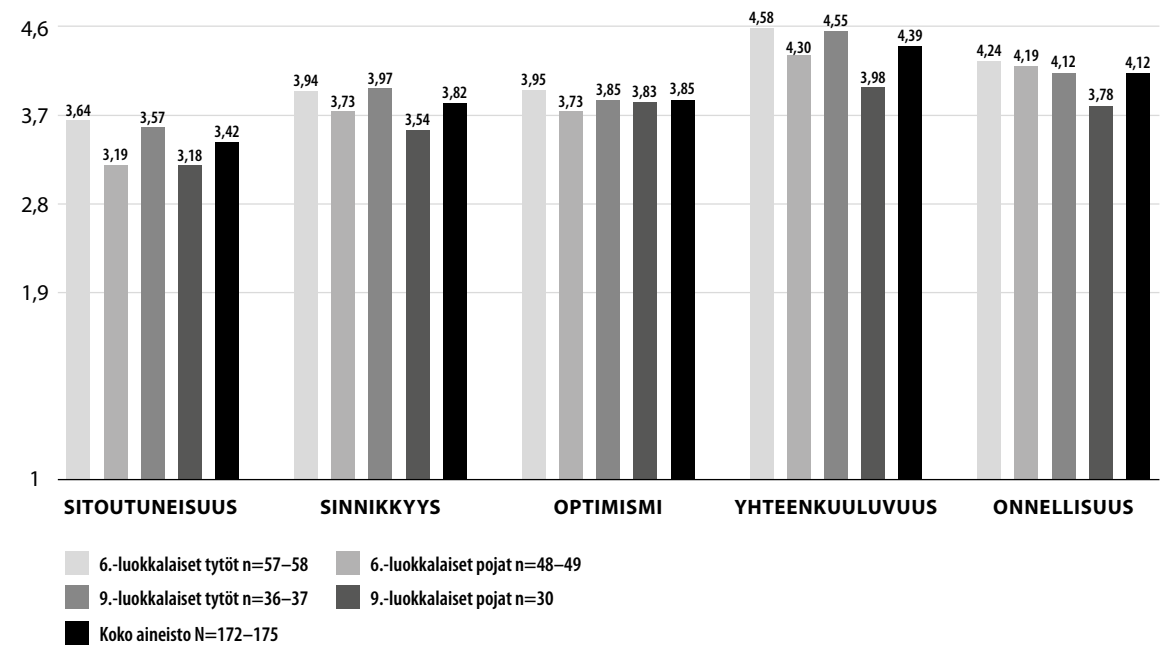

Kuvio 1 Erot hyvinvoinnin eri osa-alueiden kokemuksissa kuudes- ja yhdeksäsluokkalaisilla tytöillä, pojilla ja koko aineistossa, asteikko 1-5

\section{Johtopäätökset ja pohdinta}

Tässä tutkimuksessa tarkasteltiin kuudes- ja yhdeksäsluokkalaisten tyttöjen ja poikien kokemuksia hyvinvoinnista, kouluonnellisuudesta ja vahvuuksien käytöstä Seligmanin (2011) PERMA-teoriaan pohjautuen. Tar- 
koituksena oli selvittää vastaajien subjektiivisia näkemyksiä, jotta hyvinvointia edistävät tekijät voitaisiin koulussa kohdentaa paremmin. Kuten aiemmissa tutkimuksissa on osoitettu, kuudes- ja yhdeksäsluokkalaiset voivat keskimäärin hyvin, koulu näyttäytyy heille myönteisenä paikkana ja suurin osa pystyy toimimaan vahvuuksillaan (Terveyden ja hyvinvoinnin laitos 2019; Uusitalo-Malmivaara 2012). Kuitenkin myös poikkeuksia oli. Pieni osa vastaajista raportoi erittäin alhaisesta hyvinvoinnista, ja kouluonnellisuus laski kaikilla yhdeksännellä luokalla.

Miksi koulussa koettu onnellisuus laskee yläkoulussa? Oletusarvoisesti kuudesluokkalaisilla on vielä toinen jalka lapsuudessa, toinen nuoruudessa. Yhdeksäsluokkalaisilla taas murrosikä on tuonut omat erityispiirteensä arjen kokemuksiin oman identiteetin muotoutuessa uudelleen samalla, kun ympäristön vaateet kasvavat (Thomaes, Sedikides, van den Bos, Hutteman \& Reijntjes 2017, 1052). Myös sukupuoli on yhteydessä kokemuksiin, joiden perusteella koulu ja elämä yleensäkin näyttäytyvät (Morojele 2011, 677). Hieman yllättäen ja aiemmista tutkimuksista poiketen (Terveyden ja hyvinvoinnin laitos 2019; Uusitalo-Malmivaara 2012; 2014) tutkimuksemme tytöt kokivat hyvinvointia poikia enemmän sekä kuudennella että yhdeksännellä luokalla, eikä tyttöjen hyvinvointi laskenut merkitsevästi yläkouluun siirryttäessä. Tulos on tyttöjen osalta rohkaiseva, mutta poikien osalta hieman hälyttävä.

Seligmanin (2011) PERMA-teoria tarkastelee hyvinvointia kukoistuksen tarpeiden näkökulmasta ja on monelta osin yhteneväinen itseohjautuvuusteorian (Deci \& Ryan 2000) kanssa. PERMA-teoria pyrkii selittämään, mitä tarvitaan, jotta yksilöt voisivat elämässään mahdollisimman hyvin. Tässä tutkimuksessa sukupuolten ja luokka-asteiden välisten erojen tarkemmaksi selvittämiseksi hyvinvointia tarkasteltiin PERMA-teoriaan pohjautuvan EPOCH-mittarin viidellä osa-alueella (sitoutuneisuus, sinnikkyys, optimismi, yhteenkuuluvuus ja onnellisuus). Sekä kuudes- että yhdeksäsluokkalaiset tytöt osoittivat samanikäisiä poikia suurempaa sitoutuneisuutta ja yhteenkuuluvuutta. Yhdeksännellä luokalla tytöt kokivat myös enemmän sinnikkyyttä kuin pojat. Sitoutuneisuuden väittämät koskevat oppimisesta nauttimista ja tekemiseen uppoutumista, jota PERMA-teoriassa (Seligman 2011) kuvataan muun muassa flow-kokemuksilla. Koulutyö tai muu tekeminen ei näyttänyt tuottavan pojille yhtä paljon sitoutumisen kokemusta kuin tytöille. Voisi kuvitella, että esimerkiksi harrastaminen ja pelaaminen (ks. myös Purhonen, Poikolainen, Pylvänen \& Kallunki 2020) tarjoaisivat sitoutumisen kokemuksia ja "flow'ta" runsaas- 
tikin. Saattaa olla, että koulussa teetetty kysely johti vastaajat ajattelemaan vain koulumaailmaa, ja siellä tytöt aidosti kokivat enemmän sitoutuneisuutta. Myös Salmela-Aron ja Upadayan (mm. 2011) tekemät tutkimukset puoltavat tulkintaa tyttöjen poikia suuremmasta sitoutuneisuudesta koulutyöhön. Tyttöjen suurempi tunnollisuus saattaa myös olla tuloksen takana (esim. Schmitt, Realo, Voracek \& Allik 2008; Dumfart \& Neubauer 2016). Tämä on hyvin tutkittu ilmiö, jonka taustalla ovat vaikuttaneet yhteiskunnalliset odotukset ja normit. Suomessa valtioneuvoston teettämässä tuoreehkossa selvityksessä tyttöihin ja poikiin kohdistuvat kouluodotukset nähtiin kuitenkin vain jossain määrin sukupuolistereotyyppisinä ja variaation katsottiin suurelta osin olevan yksilöiden eikä sukupuolten välistä (Pöysä \& Kupiainen 2018). Kaikkiaan tuloksemme osoittavat, että koulujen on edelleen kehityttävä palvelemaan heterogeenistyvää oppilasjoukkoa ja kuultava myös oppilaita itseään etenkin yläkouluvaiheessa, jotta jokaisen kiinnostuksen kohteet ja taipumukset voisivat kohdata opetussuunnitelman vaateet hedelmällisesti.

Tyttöjen paremmat yhteenkuuluvuuden kokemukset antavat nekin aihetta lisätutkimuksille. Tälle hyvinvoinnin osa-alueelle osuvat kyselyn väittämät koskivat läheisyyden kokemuksia ja tunnetta siitä, että ympärillä on luotettavia, rakastavia ihmisiä. Kenties kysymykset ymmärrettiin vain aivan läheisiä ja sydänystävyyksiä koskeviksi. Poikien taipumus ryhmäytyä ja liikkua laajemmissa ryhmissä ennemmin kuin kenties syvällisiäkin asioita jakavissa pareissa, saattoi näkyä vastauksissa. Havaintoon on kuitenkin kiinnitettävä huomiota, sillä yhteenkuuluvuuden tunteet ja vastaavasti yksinäisyyden kokemusten välttäminen ovat keskeisiä hyvinvoinnin tekijöitä, jotka rakentavat resilienssiä pitkälle aikuisuuteen (Seligman 2011). Läheisiin ihmissuhteisiin ja mahdollisuuteen kokea yhteisöllisyyttä liittyy keskeisesti ihmisten välinen luottamus. Kuten Maunu (2018, 11) kirjoittaa, sosiaalista luottamusta rakennetaan arkipäivän tilanteissa. Siihen koulu tarjoaa mahdollisuuksia tunti tunnilta ja välitunti välitunnilta. Sosiaalisten suhteiden ja yhteiskuntaan kiinnittymisen tukeminen ovat koulutuksen ensisijaisia tehtäviä. Tämän tutkimuksen tulosten perusteella poikien mahdollisuuteen rakentaa positiivisia vertaissuhteita on kiinnitettävä erityistä huomiota.

Tyttöjen poikia suurempi sinnikkyys yhdeksännellä luokalla on linjassa aiempien tutkimusten kanssa. Sinnikkyys ja tunnollisuus korreloivat, samoin sinnikkyys, itsesäätelykyky ja menestyminen koulutyössä eli saavuttaminen (Duckworth \& Seligman 2006), joka on sekin tärkeä hyvin- 
voinnin tekijä myös PERMA-teoriassa (Seligman 2011). Sinnikkyys on luonteenvahvuus ja harjoittamalla edistettävä taito (Peterson \& Seligman 2004; Uusitalo-Malmivaara \& Vuorinen, 2015). Tuloksemme osoittavat sinnikkyyden, samoin kuin muiden (luonteen)vahvuuksien opettamisen tärkeyden peruskoulun yläluokkiin asti. Omassa aineistossamme erityisesti yhdeksänsien luokkien pojat näyttäisivät hyötyvän vahvuusopetuksesta. Se voisi antaa työkaluja, joiden avulla sitoutua työskentelyyn ja saada siten saavuttamisen kokemuksia. Luonteenvahvuuksien opettamiseen kuuluvat kiinteästi myös sosiaaliset taidot, jotka edelleen lisäävät yhteenkuuluvuuden mahdollisuuksia. Koulussa koettu hyvinvointi riippuu sekä opinnoissa menestymisestä että myönteisistä ihmissuhteista, ja yleensä ne tukevat toinen toisiaan (mm. López-Pérez \& Fernández-Castilla 2018). Sosiaalisten taitojen opettaminen voi siten olla avain myös opinnoissa menestymiseen.

Yleisesti ottaen tuloksemme ovat yhteydessä aiempaan tutkimustietoon vahvuuksien käytön yhteydestä hyvinvointiin ja kouluonnellisuuteen (Gillham ym. 2011; Park ym. 2004; Proctor ym. 2011; Vuorinen ym. 2020; Wagner ym. 2020). Vahvuuksien käytössä ei ollut eroja sukupuolten eikä luokka-asteiden välillä. Hyvinvoinnin, kouluonnellisuuden ja vahvuuksien käytön välisiä yhteyksiä tutkittaessa havaitsimme muutoksen yhdeksänsien luokkien pojilla. Hyvinvointi ei enää korreloinut positiivisesti vahvuuksien käytön kanssa, eivätkä kouluonnellisuus ja vahvuuksien käyttö myöskään enää korreloineet keskenään kuten kuudennella luokalla ja vielä yhdeksännen tytöillä. Tulos on kiinnostava ja vaatii lisätarkasteluja. Onko niin, että ainakin osalla yläkoulupojista itsetuntemus vahvuuksien osalta on vähentynyt, vai onko koulu ja muukin elämä muuttunut sellaiseksi, ettei omia vahvuuksia enää koeta voivan käyttää? Otoksemme pojilla optimismin ja onnellisuuden osa-alueet eivät kuitenkaan olleet alhaisempia kuin tytöillä. Tämä voi kertoa poikien tyttöjä suuremmasta huolettomuudesta tai uskosta elämän kantamiseen alueilla, joita tämä kysely ei tavoittanut.

Koulun tulisi olla esimerkki osallisuutta ja toimijuutta mahdollistavasta sosiaalisesta kontekstista, jossa kaikki voivat kokea kukoistavansa ja tulevansa nähdyiksi vahvuuksiensa kautta. Tämä tarkoittaa entistä laaja-alaisemman osaamisen tunnistamista ja arvostamista ja tietoista tukea niille, joiden lähtökohdat ovat heikommat. Pudokkuus ja syrjäytyminen eivät ole sattumanvaraisia vaan suurelta osin tunnistettavissa jo varhaiskasvatuksessa. Suurimpia riskejä ovat vanhempien matala koulutustaso, 
päihde- ja mielenterveysongelmat, pitkäaikainen toimeentulotuen tarve ja perheen rakenteessa tapahtuneet suuret muutokset (Hilli, Ståhl, Merikukka \& Ristikari 2017, 665).

Tämän tutkimuksen luotettavuutta tarkasteltaessa on otettava huomioon useita seikkoja. Tulokset perustuvat vain kolmen koulun oppilaiden subjektiivisiin havaintoihin omasta hyvinvoinnistaan, kouluonnellisuudestaan ja vahvuuksien käytöstään. Esimerkiksi vahvuuksien käytön arvioimiseksi myös opettajien ja huoltajien havainnot olisivat olleet arvokkaita. Kaiken kaikkiaan tutkimuksemme otos oli pieni, vertailtavat ryhmät eivät olleet samankokoisia, eivätkä luokka-astevertailuiden osoittamat erot perustuneet toistomittaukseen, vaan otokset vertailtavissa luokka-asteissa olivat toisistaan riippumattomia. Tutkimuksemme rajoituksena on myös mainittava, että käsittelimme vain kahta sukupuolta ja on näin ollen mahdollista, että ne oppilaat, jotka eivät identifioineet itseään tytöksi tai pojaksi, ovat jättäneet vastaamatta kyselyyn. Kaikkiaan tutkimuksemme teoreettinen viitekehys on yksilökeskeinen, ja tuo hyvinvoinnista esiin vain yhden näkökulman. Tutkimuksessamme ei oteta huomioon esimerkiksi huono-osaisuuden tai erityisen tuen tarpeiden vaikutusta vastaajien kokemuksiin.

Tuloksemme antavat tietoa siitä, miten hyvinvointi, kouluonnellisuus ja vahvuuksien käyttö ovat yhteydessä toisiinsa eri ikäisillä tytöillä ja pojilla. Tuloksemme horjuttavat yleistä käsitystä hyvinvoinnin vähenemisestä yläkouluiässä ennen kaikkea tytöillä. Vertailtaessa aiempiin tutkimuksiin (Terveyden ja hyvinvoinnin laitos 2019; Uusitalo-Malmivaara 2014) on toki muistettava erilaisten mittareiden antavan toisistaan poikkeavaa näkökulmaa hyvinvointiin. Käyttämämme EPOCH-mittari (Kern ym. 2016) koostuu viidestä, hyvinvointia eri tulokulmista lähestyvästä osa-alueesta. Tutkimuksessamme pojat eivät olleet millään näistä osa-alueista tyttöjä edellä.

Tulostemme pohjalta tehdyt johtopäätökset voivat toimia suuntaa-antavina tulevaisuuden tutkimuksille ja käytännön työlle kouluissa. Erityisesti erot hyvinvoinnin eri osa-alueiden kokemisessa tarjoavat tietoa niistä tekijöistä, joita edistämällä lasten ja nuorten elämää voidaan tukea. Kouluilla on mahdollisuus tasoittaa lasten eri taustoista johtuvia eroja ja vaikuttaa lasten ja nuorten hyvinvointiin monin tavoin muun muassa eksplisiittisesti hyvinvointiin liittyviä taitoja opettamalla (Badri ym. 2018; Vuorinen ym. 2020) kuten opetussuunnitelmamme vaatiikin (Perusopetuksen opetussuunnitelman perusteet 2014,16 ). Vielä paremmin voisi sa- 
noa, että peruskoulu ja varhaiskasvatus ovat ainoita paikkoja, joissa koko ikäluokalle voidaan opettaa omaan hyvinvointiin ja siitä huolehtimiseen liittyviä taitoja. Olisiko mahdollista rakentaa koulu, joka tarjoaisi kaikille riittävästi mielenkiintoisia tavoitteita ja haasteita ja jossa jokainen pääsisi turvallisessa ympäristössä kokemaan sitoutuneisuutta ja saisi onnistumisen kokemuksia?

\section{LÄHTEET}

Backman, A. 2020. Sosiaalipedagogina Hyvinvoinnin tilassa. Teoksessa L. Unkari-Virtanen (toim.) Hyvinvointiaktivistin käsikirja. Helsinki: Metropolia Ammattikorkeakoulu. Saatavissa https://www.hyvinvointiaktivisti.fi/hyvinvoinnintila/sosiaalipedagogina-hyvinvoinnin-tilassa/ (haettu 23.6.2021).

Badri, M., Al Nuaimi, A., Guang, Y., Al Sheryani, Y. \& Al Rashedi, A. 2018. The effects of home and school on children's happiness: a structural equation model. International Journal of Child Care and Education Policy (Seoul) 12 (1), 1-16. DOI: https://doi. org/10.1186/s40723-018-0056-z.

Baumgardner, S. R. \& Crothers, M. K. 2014. Positive psychology. Harlow: Pearson Education Limited.

Boniwell, I. 2012. Positive Psychology in a Nutshell: The Science of Happiness (3rd Edition). Maidenhead: McGraw-Hill Education.

Businaro, N., Pons, F. \& Albanese, O. 2015. Do Intelligence, Intensity of Felt Emotions and Emotional Regulation Have an Impact on Life Satisfaction? A Quali-quantitative Study on Subjective Wellbeing with Italian Children Aged 8-11. Child Indicators Research 8 (2), 439-458. DOI: https://doi.org/10.1007/s12187-014-9250-x.

Csíkszentmihályi, I. \& Csíkszentmihályi, M. 1992. Optimal experience: psychological studies of flow in consciousness. Cambridge: Cambridge University Press.

Csíkszentmihályi, M. \& Nakamura, J. 2014. The Dynamics of Intrinsic Motivation: A Study of Adolescents. Teoksessa M. Csíkszentmihályi (ed.) Flow and the Foundations of Positive Psychology. Netherlands: Springer, 175-197. DOI: https:// doi.org/10.1007/978-94-017-9088-8.

Deci, E. \& Ryan, R. 2000. The "What" and "Why" of Goal Pursuits: Human Needs and the Self-Determination of Behavior. Psychological Inquiry 11 (4), 227-268. DOI: https:// doi.org/10.1207/S15327965PLI1104_01.

Diener, E. 2009. The science of well-being: The collected works of Ed Diener (Vol. 37). Berlin: Springer Science \& Business Media.

Dodge, R., Daly, A., Huyton, J. \& Sanders, L. 2012. The challenge of defining wellbeing. International Journal of Wellbeing 2 (3), 222-235. DOI: https://doi.org/10.5502/ijw. v2i3.4.

Duckworth, A. \& Seligman, M. 2006. Self-Discipline Gives Girls the Edge: Gender in SelfDiscipline, Grades, and Achievement Test Scores. Journal of Educational Psychology 98 (1), 198-208. DOI: https://doi.org/10.1037/0022-0663.98.1.198. 
Dumfart, B. \& Neubauer, A. C. 2016. Conscientiousness Is the Most Powerful Noncognitive Predictor of School Achievement in Adolescents. Journal of Individual Differences 37 (1), 8-15. DOI: https://doi.org/10.1027/1614-0001/a000182.

Fernström, N. 2021. Kuudes- ja yhdeksäsluokkalaisten subjektiivinen hyvinvointi. Pro gradu -tutkielma, Helsingin yliopiston kasvatustieteellinen tiedekunta. Helsinki: Helsingin yliopisto.

Fredrickson, B. L. 2001. The role of positive emotions in positive psychology: The broaden-and-build theory of positive emotions. American psychologist 56 (3), 218226. DOI: https://doi.org/10.1037/0003-066X.56.3.218.

Fredrickson, B. 2004. The broaden-and-build theory of positive emotions. Philosophical Transactions of the Royal Society B 359 (1449), 1367-1377. DOI: https://doi. org/10.1098/rstb.2004.1512.

Gillham, J., Adams-Deutsch, Z., Werner, J., Reivich, K., Coulter-Heindl, V., Linkins, M., Winder, B., Peterson, C., Park, N., Abenavoli, R., Contero, A. \& Seligman, M. 2011. Character strengths predict subjective well-being during adolescence. The Journal of Positive Psychology 6 (1), 31-44. DOI: https://doi.org/10.1080/17439760.2010.536773.

Govindji, R. \& Linley, P. A. 2007. Strengths use, self-concordance and well-being: Implications for strengths coaching and coaching psychologists. International Coaching Psychology Review 2 (2), 143-153.

Harinen, P. \& Halme, J. 2012. Hyvä, paha koulu. Kouluhyvinvointia hakemassa. Verkkojulkaisuja 56. Helsinki: Suomen UNICEF, Nuorisotutkimusverkosto/ Nuorisotutkimusseura. Saatavissa http://www.nuorisotutkimusseura.fi/images/ julkaisuja/Hyva_paha_koulu.pdf (haettu 22.6.2021).

Hilli, P., Ståhl, T., Merikukka, M. \& Ristikari, T. 2017. Syrjäytymisen hinta - case investoinnin kannattavuuslaskelmasta. Yhteiskuntapolitiikka 82 (6), 663-675. Saatavissa https://media.sitra.fi/2018/01/10105537/yp1706hilliym.pdf (haettu 23.6.2021).

Honkasilta, J., Ahtiainen, R., Hienonen, N. \& Jahnukainen, M. 2019. Inclusive and Special Education and the Question of Equity in Education: The Case of Finland. Teoksessa M. J. Schuelka, C. J. Johnstone, G. Thomas \& A. J. Artiles (eds.) The SAGE Handbook on Inclusion and Diversity in Education. London: Sage Publications, 481-495. DOI: https://doi.org/10.4135/9781526470430.n39.

Huppert, F. \& So, T. 2011. Flourishing Across Europe: Application of a New Conceptual Framework for Defining Well-Being. Social Indicators Research 110 (3), 837-861. DOI: https://doi.org/10.1007/s11205-011-9966-7.

Ivens, J. 2007. The development of a happiness measure for schoolchildren. Educational Psychology in Practice 23 (3), 221-239. DOI: https://doi. org/10.1080/02667360701507301.

Jayawickreme, E., Forgeard, M. \& Seligman, M. 2012. The Engine of Well-Being. Review of General Psychology 16 (4), 327-342. DOI: https://doi.org/10.1037\%2Fa0027990.

Kern, M., Benson, L., Steinberg, E. \& Steinberg, L. 2016. The EPOCH Measure of Adolescent Well-Being. Psychological Assessment 28 (5), 586-597. DOI: https://doi. org/10.1037/pas0000201. 
Laininen, E. \& Salonen, A. O. 2019. Koulutusorganisaatiot yhteiskunnan uudistajina. Sosiaalipedagoginen aikakauskirja 20, 61-72. DOI: https://doi.org/10.30675/ sa.80443.

Leskisenoja, E. 2016. Vuosi koulua, vuosi iloa: PERMA-teoriaan pohjautuvat luokkakäytänteet kouluilon edistäjinä. Väitöskirja. Rovaniemi: Lapin yliopisto. Saatavissa https://auda.ulapland.fi/bitstream/handle/10024/62568/Leskisenoja_ Eliisa_ActaE198_pdfA.pdf?sequence=2\&isAllowed=y (haettu 22.6.2021).

López-Pérez, B. \& Fernández-Castilla, B. 2018. Children's and Adolescents' Conceptions of Happiness at School and Its Relation with Their Own Happiness and Their Academic Performance. Journal of Happiness Studies 19 (6), 1811-1830. DOI: https://doi.org/10.1007/s10902-017-9895-5.

Madsen, B. 2011. Socialpedagogik. Integration och inklusion i det moderna samhället. Malmö: Studentlitteratur.

Maslow, A. H. 2013. Toward a psychology of being. New York: Simon and Schuster.

Maunu, A. 2018. Sosiaalinen luottamus ryhmäilmiönä: Tapaustutkimus ammatillisista opiskelijaryhmästiä. Sosiaalipedagoginen Aikakauskirja 19, 9-42. DOI: https://doi. org/10.30675/sa.70196.

McCullough, G. \&Huebner, E. 2003. Life Satisfaction Reports of Adolescents with Learning Disabilities and Normally Achieving Adolescents. Journal of Psychoeducational Assessment 21 (4), 311-324. DOI: https://doi.org/10.1177/073428290302100401.

Morojele, P. 2011. What does it mean to be a boy? Implications for girls' and boys' schooling experiences in Lesotho rural schools. Gender and Education 23 (6), 677693. DOI: https://doi.org/10.1080/09540253.2010.527828.

Nivala, E. 2007. Sosiaalipedagogiikka nuorten yhteiskunnallisen kasvun tukena. Sosiaalipedagoginen aikakauskirja 8, 77-107. Saatavissa https://www.academia. edu/37032409/Sosiaalipedagogiikka_nuorten_yhteiskunnallisen_kasvun_tukena (haettu 22.6.2021).

Nivala, E. \& Ryynänen, S. 2019. Sosiaalipedagogiikka. Kohti inhimillisempää yhteiskuntaa. Helsinki: Gaudeamus.

Norrish, J. M. 2015. Positive Education: The Geelong Grammar School Journey. Oxford: Oxford University Press.

Ohisalo, M., Laihiala, T. \& Saari, J. 2015. Huono-osaisuuden ulottuvuudet ja kasautuminen leipäjonoissa. Yhteiskuntapolitiikka 80 (5), 435-446. Saatavissa https:// www.julkari.fi/bitstream/handle/10024/127067/yp1505_ohisaloym.pdf?sequence=3 (haettu 22.6.2021).

Opetusministeriö 2007. Erityisopetuksen strategia. Opetusministeriön työryhmämuistioita ja selvityksiä 2007:47. Helsinki: Opetusministeriö. Saatavissa https://julkaisut.valtioneuvosto.fi/bitstream/handle/10024/79498/tr47. pdf? sequence=1 (haettu 22.6.2021).

Park, N., Peterson, C. \& Seligman, M. 2004. Strengths of character and well-being. Journal of Social and Clinical Psychology 23 (5), 603-619. DOI: https://doi.org/10.1521/ jscp.23.5.603.50748. 
Perusopetuksen opetussuunnitelman perusteet 2014. Helsinki: Opetushallitus. Saatavissa https://www.oph.fi/sites/default/files/documents/perusopetuksen_ opetussuunnitelman_perusteet_2014.pdf (haettu 22.6.2021).

Peterson, C. \& Seligman, M. 2004. Character strengths and virtues: a handbook and classification. Washington, DC: American Psychological Association.

Positive Learning 2021. Saatavissa https://positive.fi/ (haettu 11.11.2021).

Proctor, C., Maltby, J. \& Linley, P. 2011. Strengths Use as a Predictor of Well-Being and Health-Related Quality of Life. Journal of Happiness Studies 12 (1), 153-169. DOI: https://doi.org/10.1007/s10902-009-9181-2.

Purhonen, K., Poikolainen, J., Pylvänen, S. \& Kallunki, V. 2020. Pelit ja pelillisyys houkuttelevat nuoria osallistumaan ja tuottavat osallisuutta - esimerkkinä kaksi kehittämishanketta. Sosiaalipedagoginen aikakauskirja 21, 87-110. DOI: https://doi. org/10.30675/sa.70184.

Pöysä, S. \& Kupiainen, S. (toim.) 2018. Tytöt ja pojat koulussa: miten selättää poikien heikko suoriutuminen peruskoulussa? Valtioneuvoston selvitys- ja tutkimustoimikunnan julkaisusarja, 36/2018. Helsinki: Valtioneuvoston kanslia. Saatavissa http://urn.fi/ URN:ISBN:978-952-287-541-9 (haettu 23.6.2021).

Raatikainen, E., Rahikka, A., Saarnio, T. \& Vepsä, P. 2020. Ammattina sosionomi. Helsinki: Sanoma Pro Oy.

Rask, K., Åstedt-Kurki, P., Paavilainen, E. \& Laippala, P. 2003. Adolescent subjective wellbeing and family dynamics. Scandinavian Journal of Caring Sciences 17 (2), 129-138. DOI: https://doi.org/10.1046/j.0283-9318.2002.00118.x.

Ruggeri, K., Garcia-Garzon, E., Maguire, Á., Matz, S. \& Huppert, F. A. 2020. Well-being is more than happiness and life satisfaction: a multidimensional analysis of 21 countries. Health and quality of life outcomes 18 (1), 1-16. DOI: https://doi.org/10.1186/ s12955-020-01423-y.

Saikkonen, P., Karvonen, S. \& Kestilä, L. 2019. Katse kohti hyvinvointipolitiikan tulevaisuutta. Teoksessa L. Kestilä \& S. Karvonen (toim.) Suomalaisten hyvinvointi 2018. Helsinki: Terveyden ja hyvinvoinnin laitos, 332-346. Saatavissa http://urn.fi/ URN:NBN:fi-fe201903016813 (haettu 22.6.2021).

Salmela-Aro, K., Kiuru, N., Pietikäinen, M. \& Jokela, J. 2008. Does School Matter? The Role of School Context in Adolescents' School-Related Burnout. European Psychologist 13 (1), 12-23. DOI: https://doi.org/10.1027/1016-9040.13.1.12.

Salmela-Aro, K. \& Upadaya, K. 2011. The Schoolwork Engagement Inventory: Energy, Dedication, and Absorption (EDA). European Journal of Psychological Assessment 28 (1), 60-67. DOI: https://doi.org/10.1027/1015-5759/a000091.

Seligman, M. E. P. 2011. Flourish: A visionary new understanding of happiness and wellbeing. New York: Simon \& Schuster.

Seligman, M. 2018. PERMA and the building blocks of well-being. The Journal of Positive Psychology 13 (4), 333-335. Saatavissa https://ppc.sas.upenn.edu/sites/default/files/ permawellbeing.pdf (haettu 22.6.2021). 
Seligman, M., Ernst, R., Gillham, J., Reivich, K. \& Linkins, M. 2009. Positive education: positive psychology and classroom interventions. Oxford Review of Education 35 (3), 293-311. DOI: https://doi.org/10.1080/03054980902934563.

Schmitt, D. P., Realo, A., Voracek, M. \& Allik, J. 2008. Why can't a man be more like a woman? Sex differences in Big Five personality traits across 55 cultures. Journal of personality and social psychology 94 (1), 168. DOI: https://doi.org/10.1037/00223514.94.1.168.

Simel, S. 2020. Education for a positive self-image in a contemporary school. Journal of Education Culture and Society 4 (2), 108-115. DOI: https://doi.org/10.15503/ jecs20132.108.115.

Sitra 2017. Tekoäly kertoo mitä Suomi osaa ja positiivinen CV kaivaa nuorten piilevän osaaminen esiin: Sitran miljoonan euron Ratkaisu 100 -haastekilpailu ratkesi. Saatavissa https://www.sitra.fi/uutiset/tekoaly-kertoo-mita-suomi-osaa-japositiivinen-cv-kaivaa-nuorten-piilevan-osaaminen-esiin-sitran-miljoonan-euronratkaisu-100-haastekilpailu-ratkesi/ (haettu 22.6.2021).

Terveyden ja hyvinvoinnin laitos 2019. Lasten ja nuorten hyvinvointi - Kouluterveyskysely 2019. Tilastoraportti 33/2019. Saatavissa http://urn.fi/URN:NBN:fi-fe2019091528281 (haettu 22.6.2021).

Thomaes, S., Sedikides, C., van den Bos, N., Hutteman, R. \& Reijntjes, A. 2017. Happy To Be "Me?": Authenticity, Psychological Need Satisfaction, and Subjective Well-Being in Adolescence. Child Development 88 (4), 1045-1056. DOI: https://doi.org/10.1111/ cdev. 12867.

Thorburn, M. 2014. Educating for well-being in Scotland: policy and philosophy, pitfalls and possibilities. Oxford Review of Education 40 (2), 206-222. DOI: https://doi.org/ 10.1080/03054985.2014.891981.

Thuneberg, H. 2007. Is a Majority Enough?: Psychological Well-being and Its Relation to Academic and Prosocial Motivation, Sef-regulation and Achievement at School. Saatavissa http://urn.fi/URN:ISBN:978-952-10-3846-4 (haettu 22.6.2021).

Tobia, V., Greco, A., Steca, P. \& Marzocchi, G. 2019. Children's Wellbeing at School: A Multi-dimensional and Multi-informant Approach. Journal of Happiness Studies 20 (3), 841-861. DOI: https://doi.org/10.1007/s10902-018-9974-2.

Unicef 1989. Lapsen oikeuksien sopimus. Saatavissa https://www.google.com/ url?q=https://www.unicef.fi/lapsen-oikeudet/sopimus-kokonaisuudessaan/\&sa=D\& source $=$ editors \&ust $=1624436592640000 \& u s g=A O v V a w 3 U m p P 2 r x w n D D 4 u W p B d b$ Tj2 (haettu 23.6.2021).

Uusiautti, S. 2014. On the positive connection between success and happiness. International Journal of Research Studies in Psychology 3 (1), 85-96. DOI: https:// doi.org/10.5861/ijrsp.2013.509.

Uusitalo-Malmivaara, L. 2012. Global and School-Related Happiness in Finnish Children. Journal of Happiness Studies 13 (4), 601-619. DOI: https://doi.org/10.1007/s10902011-9282-6. 
Uusitalo-Malmivaara, L. 2014. Happiness Decreases during Early Adolescence - A Study on 12- and 15-Year-Old Finnish Students. Psychology 5, 541-555. DOI: http://dx.doi. org/10.4236/psych.2014.56064.

Uusitalo-Malmivaara, L., Kankaanpää, P., Mäkinen, T., Raeluoto T., Rauttu, K., Tarhala, V. \& Lehto, J. E. 2012. Are Special Education Students Happy? Scandinavian Journal of Educational Research 56 (4), 419-437. DOI: https://doi.org/10.1080/00313831.20 11.599421.

Uusitalo-Malmivaara, L., \& Vuorinen, K. 2015. Huomaa hyvä! Näin ohjaat lasta ja nuorta löytämään luonteenvahvuutensa. Jyväskylä: PS-kustannus.

Vaistela, K. 2019. Paluu oppimisesta opettamiseen ja kasvatus kohti aikuisuutta. Sosiaalipedagoginen aikakauskirja 20, 105-109. DOI: https://doi.org/10.30675/ sa.88599.

Vuorinen, K., Erikivi, A. \& Uusitalo-Malmivaara, L. 2019. Journal of Research in Special Educational Needs 19 (1), 45-57. DOI: https://doi.org/10.1111/1471-3802.12423.

Vuorinen, K., Hietajärvi, L. \& Uusitalo, L. 2020. Students' Usage of Strengths and General Happiness are Connected via School-related Factors. Scandinavian Journal of Educational Research, 1-13. DOI: https://doi.org/10.1080/00313831.2020.1755361.

Wagner, L., Gander, F., Proyer, R. \& Ruch, W. 2020. Character Strengths and PERMA: Investigating the Relationships of Character Strengths with a Multidimensional Framework of Well-Being. Applied Research in Quality of Life 15 (2), 307-328. DOI: https://doi.org/10.1007/s11482-018-9695-z.

Weber, M., Wagner, L. \& Ruch, W. 2016. Positive Feelings at School: On the Relationships Between Students' Character Strengths, School-Related Affect, and School Functioning. Journal of Happiness Studies 17 (1), 341-355. DOI: https://doi. org/10.1007/s10902-014-9597-1.

White, M. A. \& Kern, M. L. 2018. Positive education: Learning and teaching for wellbeing and academic mastery. International Journal of Wellbeing 8 (1), 1-17. DOI: https:// doi.org/10.5502/ijw.v8i1.588. 
138 - Sosiaalipedagoginen aikakauskirja, vuosikirja 2021, vol. 22 